\title{
GÊNERO E MEIO AMBIENTE EM ESTUDO DE REVISÃO DA PESQUISA SOCIAL SOBRE DESIGUALDADE SOCIO- AMBIENTAL NO BRASIL
}

\section{GENDER AND ENVIRONMENT IN REVIEW STUDY OF SOCIAL RESEARCH ON SOCIAL AND ENVIRONMENTAL INEQUALITY IN BRAZIL}

\author{
Talita Mortale \\ Universidade Federal de São Paulo, Discente do Programa de Pós Graduação em Análise Ambiental \\ Integrada PPAAI, Diadema, SP, Brasil \\ tatita.mortale@gmail.com \\ Sueli Aparecida Moreira \\ Universidade Federal do Rio Grande do Norte, docente do Curso de Graduação em Turismo. \\ Pós-doutoranda do Programa de Pós Graduação em Análise Ambiental Integrada PPAAI, \\ Universidade Federal de São Paulo, Diadema, SP, Brasil \\ suelimoreira@yahoo.com.br \\ Zysman Neiman \\ Universidade Federal de São Paulo, Docente do Programa de Pós Graduação em Análise Ambiental \\ Integrada PPAAI, Diadema, SP, Brasil. \\ zneiman@gmail.com
}

\section{Resumo}

O debate sobre gênero e meio ambiente é uma das premissas do Desenvolvimento Sustentável para alcançar a redução da desigualdade social. Portanto, o presente estudo se propõe a revisar a literatura em busca de estudos sobre gênero e meio ambiente, com impactos nos direitos sociais de mulheres. Os dados foram obtidos através de abordagem metodológica teórico-conceitual, com revisão da literatura dos últimos 10 anos focados em pesquisa social de natureza qualitativa. A análise e interpretação dos dados se deram a partir da busca de categorias expressivas dos artigos. Os resultados demonstraram que a historicidade marcada pelo patriarcado e sistema político econômico capitalista têm reforçado os padrões de desigualdade entre os gêneros. Natureza como fonte inesgotável de recursos, meio de vida e subsistência. Em conclusão, apesar da importância dos estudos qualitativos em registrar a diversidade no cotidiano feminino, são necessários estudos de intervenção para instrumentalizar a autonomia e emancipação de mulheres no campo, para assegurar o acesso ao meio ambiente sob a perspectiva do desenvolvimento sustentável.

Palavras-chave: Mulheres. Camponesas. Desigualdade Social. Pesquisa Qualitativa. 


\begin{abstract}
The debate on gender and environment is one of the premises of Sustainable Development to achieve the reduction of social inequality. Therefore, the present study proposes to review the literature for gender and environmental studies, with impacts on women's social rights. Data were obtained through a theoretical-conceptual methodological approach, with literature review of the last 10 years focused on qualitative social research. Data analysis and interpretation were based on the search for expressive categories of articles. The results showed that the historicity marked by the patriarchy and capitalist economic political system have reinforced the patterns of gender inequality. Nature as an inexhaustible source of resources, livelihoods and subsistence. In conclusion, despite the importance of qualitative studies in recording diversity in women's daily life, intervention studies are needed to equip the autonomy and emancipation of women in the countryside, to ensure access to the environment from the perspective of sustainable development.
\end{abstract}

Keywords: Women. Peasants Social inequality. Qualitative research.

\title{
Introdução
}

O complexo desequilíbrio entre o desenvolvimento econômico e a crescente taxa de degradação ambiental contribui para um cenário socioambiental cada vez mais devastado sob uma perspectiva global. A intensificação de interferências danosas no funcionamento dos ecossistemas, como a expansão demográfica indefinida e a exploração máxima dos bens naturais comprometem a regulação dos serviços ecossistêmicos, fragmentando paisagens e prejudicam sua capacidade de autorregulação (ANDRADE; ROMEIRO, 2009; CAVALCANTI; ALOUFA, 2014; JOLY et al., 2011).

$\mathrm{Na}$ tentativa de conservar o patrimônio natural ainda existente, agências internacionais de atenção a diversos problemas globais debatem sobre a necessidade da proposição de medidas de conciliação factíveis entre o homem e sistemas naturais (ANDRADE; ROMEIRO, 2009; HOEFFEL et al., 2011). No contexto do desenvolvimento sustentável, a igualdade de gênero constitui-se uma das temáticas fundamentais para se alcançar a melhoria da problemática socioambiental (CARVALHO, 2016; HERNÁNDEZ, 2010).

De acordo com Braga (2015), a inserção da temática sobre o gênero é prioritária por proporcionar que homens e mulheres reflitam e desenvolvam a perspectiva holística e transdisciplinar do planeta e com isso possam exercer seus papéis de forma igualitária na promoção da conservação ambiental. Portanto, é preciso ultrapassar a ideia de que a 
sensibilidade e o cuidado com a natureza são valores inatos femininos (CASTRO; ABRAMOVAY, 2005).

Desde a antiguidade coexiste a cultura de que o marido é responsável pelo sustento da casa e que a mulher, sendo provedora do lar, se responsabilizaria pela educação dos filhos e afazeres domésticos. Essa divisão clássica não permitiu a mulher participar ativamente das discussões sobre problemas ambientais, além de inviabilizar alternativas voltadas ao desenvolvimento sustentável propostas por elas (ANGELIN, 2014; CARVALHO, 2015). Além disso, Angelin (2014) complementa que essas relações de poder mantidas na atualidade e intensificadas pelos moldes capitalistas desumanizam as relações sociais e destroem o planeta. Nesta abordagem, torna-se prioritário ampliar as discussões sobre gênero e o papel da mulher na construção de sociedades equitativas e na desconstrução da visão antropocêntrica de meio ambiente, pois, segundo Garcia (1992), ocorre um complexo entre opressão da mulher e depreciação da natureza que colocam ambas em nível hierárquico inferior ao homem que necessita ser redimensionado.

Assim, no contexto do desenvolvimento sustentável, é preciso reconhecer o papel da mulher na redução dos padrões insustentáveis de consumo, ultrapassar o viés biológico relativo ao gênero, combater a desigualdade hierárquica fruto do histórico cultural exercido pelo sistema patriarcal, ampliar o reconhecimento sobre a luta ecofeminista, compreendendo sua história e seu potencial de solucionar as mais diversas questões socioambientais (CARVALHO, 2016; GARCIA, 1992; HERNÁNDEZ, 2010). Além disso, acreditar na possibilidade de um mundo pautado na justiça em que natureza e cidadania sejam prioritárias, com relações justas e solidárias, sob princípios éticos que não subjuguem mulheres e homens, negros e brancos, pobres e ricos, natureza e sociedade (ALMEIDA; MARTINS, 2008; BRAGA, 2015; DI CIOMMO, 2007).

Embora historicamente a libertação feminina tenha ganhado visibilidade e espaço no enfrentamento dos mais variados paradigmas contemporâneos, a inserção da mulher na formulação e no planejamento de políticas ambientais continua lenta e a emergente questão ambiental suscita por nova abordagem quanto à incorporação do gênero que, por conseguinte, perpassa o conhecimento atual das relações sociais regionais (CÓRDULA; NASCIMENTO, 2012; JACOBI et al., 2015).

Apesar da relevância da temática de gênero, muitos trabalhos acadêmicos têm centrado esforços na compreensão da relação gênero e meio ambiente apenas de maneira 
teórica, enquanto uma minoria se propôs a aprofundar a literatura por meio de estudos de caso. Vale ressaltar que, essas últimas análises, ao explorar a realidade de determinadas localidades, angariam-se resultados que podem fundamentar e nortear políticas públicas voltadas ao enfrentamento da desigualdade entre os gêneros e a promoção de atitudes sustentáveis.

Considerar a perspectiva de gênero em relação ao meio ambiente pode assegurar mecanismos de proteção na construção de uma sociedade equitativa e socialmente justa, então se elaborou a revisão da literatura sobre gênero e meio ambiente para identificar os principais aspectos que configuram as desigualdades sociais e as representações socioambientais em pesquisas sociais de natureza qualitativa.

\section{Gênero e desigualdade}

De acordo com Di Ciommo (2007), historicamente a igualdade para as mulheres perpetuou-se ilusória. Desde o início das construções sociais evidencia-se um modelo centrado na figura masculina como detentora de maior status econômico e político (SOUSA, 2010). Homens e mulheres contribuíram de maneira distinta no gerenciamento de recursos. Enquanto eles comandavam a caça e os fatores econômicos, elas tornavamse responsáveis pelo cuidado com o lar, além de desenvolverem atividades como: coleta de água e de alimentos, cultivo de plantas, criação de animais (MOURO, 2017).

Segundo Almeida e Martins (2008), o homem sempre ocupou um papel de destaque social com apelo à força e ao poder, enquanto em várias culturas a mulher apareceu de forma inferior com significativo histórico de subordinação. Observa-se que esse modelo patriarcal e introjetou a cultura da dicotomização e subjugação que através de um sistema ditatorial excluiu a mulher do processo decisório político, social e científico (ANGELIN, 2014; BRAGA, 2015).

Ao longo do desenvolvimento das sociedades, o patriarcalismo foi intensificado com a implantação político-econômica capitalista centrando-se na maximização dos lucros e exploração máxima dos bens naturais. Isso permitiu a produção de diferenças entre classes, gênero e etnia (SOUSA, 2010). Durante a Revolução industrial, o trabalho doméstico passou a ser considerado gratuito em virtude da redução salarial da classe masculina por não haver custos com obrigações domésticas. Mais tarde, as mulheres 
foram requisitadas ao mercado de trabalho devido à alta adesão dos homens às Guerras Mundiais, porém com salários inferiores e mantendo a mesma carga de trabalho doméstico (ANGELIN, 2014). Segundo Almeida e Martins (2008), a divisão sexual do trabalho se fundamenta em fatores ideológicos e culturais caracterizando-se por uma relação de opressão e dominação entre os sexos. Por esta razão, torna-se pertinente abordar a questão de gênero, pois seu entendimento auxilia na compreensão das relações entre homens, mulheres e seus espaços uma vez que estes vínculos são socialmente construídos e variam em função da cultura (HERNÁNDEZ, 2010).

Entendendo gênero como uma construção social e histórica e não como determinismo biológico dado em função de características anatômicas, verifica-se seu potencial plural, que abrange homens e mulheres em concepções diversas e que podem relatar as divergências socialmente construídas (ALMEIDA; MARTINS, 2008; SOUZA; RAMÍREZ-GÁLVEZ, 2007). Sob a ótica de Rossini e Calió (2008), o debate sobre gênero deve concentrar-se nas implicações desiguais de políticas e estratégias de desenvolvimento, especialmente nos papéis socialmente criados e impostos. Segundo os autores, têm-se englobado a questão de gênero apenas de forma teórica sem investir efetivamente em linhas de ação como o estabelecimento de políticas públicas factuais. A consequência da inclusão do gênero apenas em discursos reforça a disparidade nas relações de poder e contribuem para a dominação e subordinação de mulheres, além de refletir sobre seu acesso a recursos e direitos básicos (ALMEIDA; MARTINS, 2008; MOURO, 2017).

Assim, compreendendo a relação do patriarcalismo e do capitalismo como coexistentes na construção cultural social, torna-se primordial interpretar as oposições binárias para desmistificar a ideia de atributos "naturais" das mulheres ou homens, romper com a bifurcação entre espaço produtivo e reprodutivo e com as divisões de trabalho não equitativas (ALMEIDA; MARTINS, 2008; ARANTES; GUEDES, 2010; GARCIA, 2009; SOUZA; RAMÍREZ-GÁLVEZ, 2007). E, além disso, refletir sobre a posição de inferioridade ocupada pelo feminino, especialmente quanto às populações vulneráveis que interferem ainda mais no acesso ao mercado de trabalho, serviços básicos, produção e meios de subsistência (MOURO, 2017).

Diante desta realidade, as relações de gênero podem colaborar para a compreensão das desigualdades manifestadas nas mais diversas formas e atitudes além de refletir sobre 
a subordinação das mulheres em relação aos homens e suas influências. Diferenças salariais, as profundas discrepâncias nas relações de poder, ausência de voz na esfera política, violência física e moral, inexpressividade do trabalho doméstico e uma extensa listagem de estereótipos incorporam o debate (ALMEIDA; MARTINS, 2008; MOURO, 2017). Segundo Mouro (2017), no setor rural as desigualdades podem ser materializadas ainda no que diz respeito aos direitos de produção e acesso territorial. $O$ autor compreende que, embora a força laboral no campo tenha maior representatividade feminina, essa parcela populacional obtém menor acesso aos meios de financiamento de terras. Sobre esse dado, Ferreira e Mattos (2017), argumentam que as mulheres agricultoras enfrentam uma dupla dependência desigual. A primeira relaciona-se com a configuração inferior do camponês colocando-o como subordinado ao desenvolvimento das metrópoles, enquanto a outra se relaciona com a construção cultural do patriarcalismo e relações familiares e hierárquicas desiguais.

Ainda com relação à desigualdade, 987 milhões de analfabetos no mundo são mulheres; seus salários são em média dois a três terços menores em relação ao dos homens e sua representatividade em cargos públicos no Brasil não ultrapassa 19\%. Embora a participação feminina tenha se elevado nos últimos anos, passando de 13,6\% para mais de $50 \%$ em 60 anos, as mulheres detêm menos de $12 \%$ das terras brasileiras e apenas $4 \%$ são líderes de empresas no país (TONI et al., 2014). Segundo Pacheco (2004), o paradigma econômico atual também reforça a desigualdade entre os gêneros por desacreditar o trabalho doméstico não-pago e ignorar a divisão de atribuições entre os sexos. É preciso lembrar, também, que a classe feminina ainda pode sofrer com a sobreposição de outros fatores de desigualdade como etnia, faixa etária e classe social (ALMEIDA; MARTINS, 2008).

No que tange ao desequilíbrio ambiental, as suas consequências também atingem os gêneros de maneira desigual. De acordo com Silva (2017), a organização social familiar compete à mulher maior responsabilidade sobre a família e aos eventos que a atingem. Diante da deterioração ecológica, escassez hídrica e alimentar, muitas mulheres necessitam aumentar a carga de trabalho para garantir a subsistência própria e da família, especialmente aquelas margeadas por condição de subemprego (SOUSA, 2010; TORNQUIST et al., 2010). 
Quanto ao desempenho no processo de decisão, Mouro (2017) lembra que sua representatividade em órgãos e associações relacionadas à questão ambiental é minoria inclusive com relação a ações de mitigação que não contam com a participação feminina nos planos de ação, além de ignorar os conhecimentos tradicionais por elas construídos em atividades agrícolas.

Ao se debater as inúmeras formas de desigualdade entres os gêneros, verifica-se a influência do modelo capitalista e patriarcal para a cultura brasileira que, por conseguinte, dificulta a garantia de direitos, reconhecimento político e participação social feminina (SOUSA, 2010). Diante dessa realidade, é preciso reconstruir o modelo de interdependência entre gêneros, etnias e classes fundamentada na equidade em que ambos os lados possam partilhar responsabilidades e colaborar efetivamente para o desenvolvimento sustentável (GARCIA, 2009; CASTRO; ABRAMOVAY, 2005).

\section{Ecofeminismo e conservação ambiental}

Ao longo do debate entre gênero e desigualdade evidenciou-se que a lógica patriarcal revoga a atuação do protagonismo feminino enquanto o ecofeminismo surge com a proposta de conquistar espaço e poder de decisão em consequência das várias lutas travadas durante a construção da sociedade. Soma-se a essa relação de opressão a falta de exercício político em meio à questão ambiental que, segundo Angelin (2014), merece ter seu histórico avaliado na busca do entendimento da relação entre mulheres e natureza.

Em decorrência do androcentrismo, apenas em 1910 os direitos sufragistas femininos foram retomados no Congresso Nacional brasileiro, após anos de diligências e ausência de expressividade nos mais variados setores sociais. Em decorrência desta arraigada desigualdade, Simone de Beauvoir lançou o livro "O segundo sexo" no ano de 1940, quando teceu reflexões sobre os variados condicionamentos sofridos pelas mulheres que a tornou alienada ao seu sexo, tornando-se um marco para a futura reflexão feminista em ascensão em 1960. Nesta época, já se debatiam questões de determinismo biológico, aprisionamento doméstico e poder político juntamente com educação, ambientalismo e feminismo na Europa (SOUZA; RAMÍREZ-GÁLVEZ, 2007). No século XX, o movimento feminista passou a questionar a hegemonia da ordem econômica, direitos civis e educação com discurso voltado a valorização e visibilidade feminina por meio da 
discussão entre gênero e desigualdade (ARANTES; GUEDES, 2010; SOUSA; RAMÍREZGÁLVEZ, 2007). Vale ressaltar que essa luta não reflete a superioridade entre os sexos, mas sua construção equitativa e socialmente justa (FERRE, 2015).

Em função das preocupações com a degradação ambiental e a expansão demográfica indefinida, intrinsecamente relacionada à subjugação sofrida pelas mulheres face ao sistema patriarcal, surgiu o Ecofeminismo sugerido por Françoise d'Eaubonne, em 1974, na França (FLORES; TREVIZAN, 2015; SOUZA; RAMÍREZ-GÁLVEZ, 2007).

Muitos foram os movimentos sociais que influenciaram a propagação do Ecofeminismo a nível mundial entre as décadas de 1970 e 1980. Entre eles pode-se elencar o Love Canal (EUA), Movimento Chipko (Índia), Clube Seikatsu (Japão) e Mulheres Campesinas do Sul (Brasil). Todas essas atividades são traduções de eventos climáticos extremos ou modelos econômicos improcedentes que suscitaram a mobilização feminina em prol do ambiente equilibrado (BRAGA, 2015). Intrínseco a esse contexto, ao final da década de 1980, as políticas tratadas em Conferências Mundiais propuseram a mudança da nomenclatura "Mulher e Desenvolvimento" para "Gênero e Desenvolvimento", por representar a incorporação feminina na busca de condições igualitárias no preceito político e ambiental (TORNQUIST et al., 2010).

O movimento do ecofeminismo pode ser considerado como uma escola de pensamento conduzida por movimentações feministas e ambientalistas que objetivam compreender instrumentos de dominação feminina e sua interconexão com a natureza (ANGELIN, 2014; SILIPRANDI, 2000). Ao aliar o universo feminista à manutenção de vida saudável, o movimento viabiliza um ponto de encontro entre as abordagens na reconstrução social pautada em princípios sustentáveis (ANGELIN, 2014). Embora seja um movimento em defesa da causa das mulheres, seu potencial abrange toda a estrutura civilizacional buscando uma forma significativa de retroceder a degradação ecológica, questionar o modelo capitalista patriarcal e propor ações para mitigar a desigualdade social, violência e a miséria (SILVA, 2017).

A temática do ecofeminismo busca analisar por que as mulheres são tratadas como inferiores pelos homens e por que a natureza é tratada como inferior à cultura, assumindo uma análise sobre os papéis de gênero e sobre os dualismos hierárquicos. Nessa direção, o movimento conta com três tendências fundamentais que valem ser mencionadas: o ecofeminismo clássico, ecofeminismo espiritualista do Terceiro Mundo e o ecofeminismo 
construtivista (TORRES, 2009). De acordo com Flores e Trevizan (2015), trata-se de abordagens conflitantes.

A primeira escola de pensamento se opõe às diferenças da própria natureza masculina tendenciosamente agressiva e obsessiva na busca de poder. O ecofeminismo espiritualista do Terceiro Mundo, influenciado por princípios religiosos, fundamenta-se na objeção das discrepâncias entre os gêneros criticando fortemente a concepção patriarcal e centralização do poder contra o antisexismo, antiracismo e antielitismo. Tratando-se do ecofeminismo construtivista. Angelin (2014) observa que essa tendência é resultante da desigualdade social do trabalho e defende a relação mútua entre mulheres, natureza e justiça socioambiental. Sob a ótica de Mouro (2017), embora haja diferenças marcantes entre as abordagens, todas apresentam forte relação entre mulheres e ambiente fomentando discussões a despeito do gênero e sociedade contemporânea que ultrapassa o determinismo biológico e justiça socioambiental.

As contribuições do ecofeminismo para a reconstrução das relações sociais são muitas. Essa concepção luta pela natureza como um sujeito ativo que reflete contextos sociais e materiais, critica a lógica patriarcal e as formas de deslegitimação feminina, estabelece vínculo entre poder social e degradação ambiental, rompe com a visão determinista de essência feminina de cuidado com o ambiente, dissemina conhecimentos etnobotânicos, protagoniza e empodera o gênero feminino valorizando conhecimentos tradicionais, amplia o acesso da mulher à formação de políticas públicas e finalmente reformula o senso comum do papel da humanidade no ciclo da vida (FERRE, 2015; GARCIA, 2009; SILIPRANDI, 2000; VIEIRA; AZEVEDO, 2018). Diante do histórico de submissão da mulher que se agrega em determinado momento com a dominação da natureza, ainda propõe a humanização da ecologia profunda promovendo novas representações éticas, sociais e ambientais, além de perseguir a utopia de mundo justo também na esfera econômica (ARANTES; GUEDES, 2010; GARCIA, 2009; JACOBI et al., 2015).

Mesmo diante do contexto lento de longas lutas por espaço, as mulheres têm conquistado visibilidade, inclusive em movimentos ambientalistas. Desde a promoção da Agenda 21 de Ação de Mulheres que antecedeu a Rio-92, temas como globalização, pobreza, educação, direitos da terra e segurança alimentar têm ressaltado a atuação feminina perante a questão ambiental (ALONSO; COSTA, 2002; CASTRO; 
ABRAMOVAY, 2005). Assim, diante da degradação ambiental em nível mundial que altera e contamina os ecossistemas, a biodiversidade e sua capacidade de autogestão, torna-se prioritário considerar a relação gênero-ambiente e os vínculos estabelecidos entre o meio e a população (CARNEIRO, 2012; ROSA et al., 2016). Quando se compreende a magnitude e o olhar transformador da participação feminina junto à preservação do ambiente analisa-se seu potencial de contribuição a partir de propostas de políticas públicas que minimizem as relações de poder entre os gêneros e promovam a construção da identidade cultural sem degradar o meio natural, avançando de forma consistente na sustentabilidade global (GARCIA, 2009; JACOBI et al., 2015; MOURO, 2017; ROSA et al., 2016).

\section{Método}

\section{Desenho do estudo}

Realizou-se estudo de abordagem metodológica teórico-conceitual, amparada em revisão da literatura do período entre Setembro e Novembro de 2018. O estudo concentrou-se em trabalhos que utilizaram a pesquisa social de natureza qualitativa envolvendo a relação entre gênero e meio ambiente em busca de categorias que retratassem o cotidiano das mulheres de contexto rural. A maioria das publicações levantadas não contemplava a parte empírica ou ida a campo da pesquisa social.

Com o objetivo de avaliar as contribuições do ecofeminismo para a Conservação Ambiental, publicadas na literatura acadêmica, a metodologia foi fundamentada na procura de trabalhos que objetivaram investigar essas colaborações por meio da pesquisa social. Iniciou-se a busca selecionando revistas Qualis A e B, segundo a classificação da Coordenação de Aperfeiçoamento de Pessoal de Nível Superior - CAPES - na Área de Ciências Ambientais e Meio Ambiente e Agrárias. Foram definidos como critérios de busca para seleção, artigos publicados nos últimos 20 anos, usando a ferramenta do Google Acadêmico, utilizando palavras-chave. Para realizar a busca nesses locais, fez-se uso das seguintes palavras-chave: Gênero e Meio Ambiente, Floresta, Ecofeminismo, Feminismo ambiental, desigualdade social, mulheres e Floresta, cujas seleções foram organizadas em categorias conforme o quadro 1. 
Quadro 1: Categorias adotadas e respectivos conteúdos durante a revisão

\begin{tabular}{|c|c|}
\hline Categoria de Análise & Critério de Agrupamento \\
\hline Metodologia & Abordagens das pesquisas qualitativas \\
\hline Organização Social/Modos de Vida & Contexto da pesquisa bem como os sujeitos \\
\hline $\begin{array}{l}\text { Gênero e Desigualdade na Divisão } \\
\text { Sexual do Trabalho }\end{array}$ & $\begin{array}{l}\text { Relações entre gêneros demonstrando possíveis disparidades } \\
\text { quanto à divisão de tarefas diárias }\end{array}$ \\
\hline Representações de Meio Ambiente & Percepção de meio ambiente sob a perspectiva de gênero \\
\hline
\end{tabular}

Durante a análise os achados das publicações selecionadas geraram um corpus cujo teor das informações indicava a elaboração de categorias. Para Pinheiro e Gunther, (2008), a pesquisa qualitativa favorece esse tipo de análise, pois permite lidar com um volume significativo de informações, qualificar dados além de facilitar uma interpretação mais profunda dos fenômenos sociais.

\section{Resultados e Discussão}

Conforme a busca bibliográfica, encontrou-se aproximadamente 65 trabalhos tratando do assunto. No entanto, apenas 16 deles trouxeram explicitadas as relações entre Gênero e Desigualdade com Representações sobre o Meio Ambiente por meio de estudos de caso. A literatura encontrada foi organizada conforme quadro 2 a seguir: 
Quadro 2. Estudos que subsidiaram as categorias de gênero e meio Ambiente

\begin{tabular}{|c|c|c|c|}
\hline Referência & Contexto & Abordagem Qualitativa & Título \\
\hline 1. ABREU, 2000 & $\begin{array}{l}\text { Parque Nacional de Jaú - } \\
\text { AM }\end{array}$ & Método Etnográfico & $\begin{array}{l}\text { Gênero, meio ambiente e modos de } \\
\text { vida da população do Parque } \\
\text { Nacional do Jaú/AM }\end{array}$ \\
\hline $\begin{array}{l}\text { 2. ALMEIDA; } \\
\text { MARTINS, } 2008\end{array}$ & $\begin{array}{l}\text { Participantes do Projeto } \\
\text { MA - São João } \\
\text { D'Aliança-GO }\end{array}$ & Método Etnográfico & $\begin{array}{l}\text { Relações de Gênero e Educação } \\
\text { Ambiental no Projeto Mulheres das } \\
\text { Águas }\end{array}$ \\
\hline 3. BRITO, 2016 & $\begin{array}{l}\text { Seringais de Manaus - } \\
\text { AM }\end{array}$ & Método de Fontes Orais & $\begin{array}{l}\text { Trabalhadoras no } \\
\text { experiência, trabalho, muitas histórias }\end{array}$ \\
\hline 6. DICIOMMO, 2007 & $\begin{array}{l}\text { Reserva Extrativista } \\
\text { Marinha da Ponta do } \\
\text { Corumbau - BA }\end{array}$ & Observação Participante & $\begin{array}{l}\text { Pescadoras e pescadores: A questão } \\
\text { da equidade de gênero em uma } \\
\text { Reserva Extrativista Marinha }\end{array}$ \\
\hline 7. FADIGAS et al., 2008 & $\begin{array}{l}\text { Estuário dos Rios } \\
\text { Goiana e Megaó - GO }\end{array}$ & $\begin{array}{l}\text { Observação Dirigida } \\
\text { Questionário Estruturado }\end{array}$ & $\begin{array}{l}\text { As contribuições das marisqueiras } \\
\text { para uma gestão sócio-ambiental em } \\
\text { reservas extrativistas }\end{array}$ \\
\hline 9. MACHADO, 2007 & $\begin{array}{l}\text { Cidades de Belém e } \\
\text { Marapanim-AM }\end{array}$ & $\begin{array}{l}\text { Produção Antropológica } \\
\text { Observação Participante }\end{array}$ & $\begin{array}{l}\text { Catadoras de caranguejo e saberes } \\
\text { tradicionais na conservação de } \\
\text { manguezais da Amazônia brasileira }\end{array}$ \\
\hline $\begin{array}{l}\text { 10. MONTYSUMA; } \\
\text { CRUZ, } 2008\end{array}$ & $\begin{array}{l}\text { Seringal Cachoeira, } \\
\text { Xapuri-AC }\end{array}$ & Relatos Orais & $\begin{array}{l}\text { Perspectivas de gênero acerca de } \\
\text { experiências cotidianas no seringal } \\
\text { Cachoeira, Acre }(1964-2006)\end{array}$ \\
\hline $\begin{array}{l}\text { 11. PERALTA; } \\
\text { ALENCAR, } 2008\end{array}$ & $\begin{array}{l}\text { Reserva de } \\
\text { Desenvolvimento } \\
\text { Sustentável Mamirauá - } \\
\text { AM }\end{array}$ & $\begin{array}{l}\text { Observação Participante e } \\
\text { Entrevistas }\end{array}$ & $\begin{array}{l}\text { Ecoturismo e Mudança Social na } \\
\text { Amazônia Rural: efeitos sobre o } \\
\text { papel da mulher e as relações de } \\
\text { gênero }\end{array}$ \\
\hline 12. SILVA et al., 2014 & $\begin{array}{ll}\text { Comunidade } & \text { Maguari, } \\
\text { Belterra - PA } & \\
\end{array}$ & $\begin{array}{l}\text { Observação Participante e } \\
\text { Método Etnográfico }\end{array}$ & Gênero e Floresta \\
\hline 13. SOUSA, 2010 & $\begin{array}{l}\text { Projeto de Assentamento } \\
\text { Equador Rorainópolis - } \\
\text { PR }\end{array}$ & Entrevista Estruturada & $\begin{array}{l}\text { Gênero e Meio Ambiente na } \\
\text { Amazônia Roraimense: Um olhar } \\
\text { sobre o encontro da água com a vida } \\
\text { de mulheres do Projeto de } \\
\text { Assentamento Equador, Rorainópolis }\end{array}$ \\
\hline 15. VALLIN, 2016 & $\begin{array}{l}\text { Cooperativa de Materiais } \\
\text { Recicláveis, São Paulo - } \\
\text { SP }\end{array}$ & $\begin{array}{l}\text { Estudo de Caso Entrevista } \\
\text { Narrativa }\end{array}$ & $\begin{array}{l}\text { Gênero e Meio Ambiente: dupla } \\
\text { jornada de injustiça ambiental em } \\
\text { cooperativa de mulheres catadoras de } \\
\text { materiais Recicláveis }\end{array}$ \\
\hline $\begin{array}{l}\text { 16. WOORTMANN, } \\
1998\end{array}$ & $\begin{array}{l}\text { Seringais do Triunfo - } \\
\text { AC }\end{array}$ & Método Etnográfico & $\begin{array}{l}\text { Família, Mulher e Meio Ambiente no } \\
\text { Seringal }\end{array}$ \\
\hline
\end{tabular}

Fonte: PPGAAI - UNIFESP, Diadema, 2018.

Org.: Dos autores, 2018.

\section{Abordagens metodológicas encontradas}

A presente categoria foi construída com base no levantamento das abordagens empregadas nos estudos de natureza qualitativa relacionados à discussão entre Gênero, Ecofeminismo e Conservação Ambiental. Além de avaliar quais metodologias têm sido empreendidas nos últimos anos, tem por intento analisar se estas ferramentas têm sido eficientes para angariar os resultados desejados diante da temática. De acordo com os dados sistematizados no quadro 3 , parcela significativa dos autores selecionados faz uso 
do método Etnográfico em suas pesquisas que segundo CAVEDON (1999), é caracterizado a seguir:

\begin{abstract}
O método etnográfico consiste no levantamento de todos os dados possíveis sobre uma determinada comunidade com a finalidade de melhor conhecer o estilo de vida ou a cultura específica da mesma. Tal método tem como locus privilegiado a Antropologia Social, exatamente porque nesta disciplina encontra-se a origem do mesmo, sendo que, hodiernamente, quando se fala em estudos de cultura, nesta área de conhecimento, inevitavelmente, fala-se em método etnográfico, fazendo com que as discussões mais aprofundadas acerca do mesmo aí se concentrem. (CAVEDON, 1999, p.4).
\end{abstract}

Este método concomitante à observação participante tende a elencar um número significativo de informações com relação ao depoente na busca do entendimento de todo o universo da pesquisa. Apesar de trazerem propostas de aprofundar a discussão entre gênero e suas mais variadas implicações, muitos dos trabalhos não esclareceram os depoimentos obtidos/ou não descreveram a área de estudo com riqueza informacional. $\mathrm{O}$ debate quanto ao gênero e sua historicidade está arraigado na construção cultural das sociedades e recebem influências decorrentes do histórico regional (ALMEIDA \& MARTINS, 2008). Assim, compreende-se que a análise ecofeminista pode tornar-se mais autenticas incorporando-se o diagnóstico/contextualização do universo de inserção dos testemunhos.

Ainda sobre o âmbito da metodologia ecofeminista, Storey (2003) ressalta que sua fundamentação não se restringe a regras estipuladas ou interpretações estereotipadas, pois o seu emprego é utilizado em contextos abertos e flexíveis na busca do entendimento de determinada realidade sob diversos ângulos. Porém, analisando-se as metodologias utilizadas nos estudos de caso selecionados, a ferramenta empregada por Di Ciommo (2007), torna-se diferenciada com relação aos resultados obtidos. 
Quadro 3: Categorias encontradas nos estudos sobre Gênero e Meio Ambiente

\begin{tabular}{|c|c|c|}
\hline Organização Social/Modo de vida & Divisão Sexual/Desigualdade de gênero & Representação do meio ambiente \\
\hline $\begin{array}{l}\text { 1. Comunidade Tradicional: Agricultura } \\
\text { Familiar e Extrativismo; Sistema de Pousio } \\
\text { para plantio. } \\
\text { Média Infraestrutura. }\end{array}$ & $\begin{array}{l}\text { Atividade feminina ligada ao campo e esfera } \\
\text { doméstica. Homens ligados à caça e } \\
\text { comercialização. Divisão de trabalho: } \\
\text { caça/pesca realizada por ambos, de forma } \\
\text { distinta (1). }\end{array}$ & $\begin{array}{l}\text { Reconhece a depredação ambiental. Vê-se } \\
\text { alienado ao Meio Ambiente, mas a } \\
\text { compreende como necessária para a } \\
\text { subsistência (1). }\end{array}$ \\
\hline $\begin{array}{l}\text { 2. Comunidade Tradicional: Atividade } \\
\text { agrícola: Lavração e criação de gado. } \\
\text { Média Infraestrutura. }\end{array}$ & $\begin{array}{l}\text { Atividade feminina restrita à esfera doméstica } \\
\text { e bem estar familiar. Trabalho de força, } \\
\text { cuidado de fazenda e produção do masculino } \\
\text { (2). }\end{array}$ & $\begin{array}{l}\text { Preocupação com a Conservação do Cerrado; } \\
\text { Concepções diferentes entre os gêneros. } \\
\text { Homem olhar político e mulher visão prática } \\
\text { (2). }\end{array}$ \\
\hline $\begin{array}{l}\text { 3. Comunidade Tradicional: Atividade: } \\
\text { seringalista e comércio em barracões. } \\
\text { Baixa Infraestrutura. }\end{array}$ & 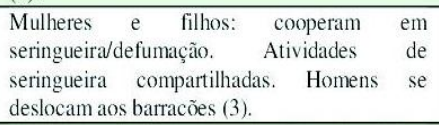 & $\begin{array}{l}\text { Natureza como meio de vida e subsistência. } \\
\text { Saber coletivo sobre ervas medicinais e } \\
\text { alimentos (3). }\end{array}$ \\
\hline $\begin{array}{l}\text { 4. Comunidade Tradicional } \\
\text { pescadores. Principal atividade: Caça e } \\
\text { Roçado. } \\
\text { Média Infraestrutura. }\end{array}$ & $\begin{array}{l}\text { Atividade feminina de domínio doméstico } \\
\text { embora desenvolva atividade de coleta de } \\
\text { caranguejos e campo. Trabalho masculino: } \\
\text { pesca (4). }\end{array}$ & $\begin{array}{l}\text { Conservação do ambiente ligado à conservação } \\
\text { de vida. Melhoramento do caranguejo como } \\
\text { forma de redução do desperdício (4). }\end{array}$ \\
\hline $\begin{array}{l}\text { 5. Comunidade Tradicional Quilombola da } \\
\text { Floresta Amazônica. Atividade: Pesca } \\
\text { Artesanal e Extrativismo. } \\
\text { Baixa Infraestrutura. }\end{array}$ & $\begin{array}{l}\text { Atividade feminina: doméstica, embora } \\
\text { participem de todos os trabalhos masculinos: } \\
\text { Atividade Seringueira, Castanheira e Pesca. } \\
\text { Masculino: Ligado à força como extrativismo } \\
\text { (5). }\end{array}$ & $\begin{array}{l}\text { Conservação do ambiente ligado à conservação } \\
\text { de vida. Ideia de Manejo Sustentável dos } \\
\text { Recursos Florestais (5). }\end{array}$ \\
\hline $\begin{array}{l}\text { 6. Comunidade Tradicional Extrativista. } \\
\text { Pesca, turismo, agricultura, coleta de } \\
\text { sementes/artesanato. } \\
\text { Baixa Infraestrutura. }\end{array}$ & $\begin{array}{l}\text { Maior envolvimento masculino na pesca. } \\
\text { Higienizar pescados, coletar mariscos e } \\
\text { semeadura a cargo do feminino. Cuidado } \\
\text { doméstico, filhos e compras envolvimento de } \\
\text { ambos (6). }\end{array}$ & Natureza como meio de vida e subsistência (6). \\
\hline $\begin{array}{l}\text { 7. Comunidade Tradicional Pesqueira. Coleta } \\
\text { de marisco. } \\
\text { Baixa Infraestrutura. }\end{array}$ & $\begin{array}{l}\text { Maior participação feminina na pesca e } \\
\text { obtenção da lenha, com predomínio do } \\
\text { masculino (7). }\end{array}$ & $\begin{array}{l}\text { Natureza como meio de vida e subsistência. } \\
\text { Tem sensibilidade para a sustentabilidade ( } 7 \text {. }\end{array}$ \\
\hline $\begin{array}{l}\text { 8. Comunidade Tradicional de Pesca } \\
\text { Artesanal em manguezal, mariscagem e coleta } \\
\text { de caranguejo. }\end{array}$ & $\begin{array}{l}\text { Homens e mulheres participam da pesca. Mas } \\
\text { a mariscagem, cuidado com os filhos e lar é do } \\
\text { feminino. Há participação dos filhos (8). }\end{array}$ & $\begin{array}{l}\text { Manguezal como dádiva divina e provedora de } \\
\text { alimento. Relação de respeito/coleta } \\
\text { sustentável (8). }\end{array}$ \\
\hline $\begin{array}{l}\text { 9. Comunidade Tradicional Amazônica de } \\
\text { Pesca e Coleta de caranguejo. } \\
\text { Baixa Infraestrutura. }\end{array}$ & $\begin{array}{l}\text { Homens fazem a pesca em alto-mar. Mulheres } \\
\text { fazem a pesca de beira, catam caranguejos e } \\
\text { respondem pelo trabalho doméstico e filhos } \\
\text { (9). }\end{array}$ & $\begin{array}{l}\text { Há reconhecimento da escassez de caranguejo } \\
\text { devido à retirada. Exploração da natureza } \\
\text { atrelada à subsistência e pobreza (9). }\end{array}$ \\
\hline $\begin{array}{l}\text { 10. Comunidade Tradicional Atividade: } \\
\text { Seringal e coleta de castanha. } \\
\text { Baixa Infraestrutura. }\end{array}$ & $\begin{array}{l}\text { Mulheres participam da seringa e roçado } \\
\text { aprendido com o pai. Atividade de comércio e } \\
\text { floresta é masculino. Cuidados domésticos e } \\
\text { colheita são exclusivamente femininos (10). }\end{array}$ & $\begin{array}{l}\text { Conhecimento da floresta é passado de geração } \\
\text { a geração. Uso da floresta para subsistência. } \\
\text { Ideia de que é preciso cuidar da floresta com } \\
\text { técnicas de Manejo Sustentável (10). }\end{array}$ \\
\hline $\begin{array}{l}\text { 11. Comunidade Tradicional Atividade } \\
\text { Econômica: Agricultura, roçado; pesca; } \\
\text { extração de madeira e cultivo de hortaliças. } \\
\text { Baixa Infraestrutura. }\end{array}$ & $\begin{array}{l}\text { Homens: Cultivo de roça e produção. } \\
\text { Mulheres ligadas ao cuidado da casa e filhos. } \\
\text { Complementaridade de serviços da mulher no } \\
\text { campo (11). }\end{array}$ & $\begin{array}{l}\text { Visão de Natureza como subsistência. } \\
\text { Ecoturismo sustentável (11). }\end{array}$ \\
\hline $\begin{array}{l}\text { 12. Comunidade Tradicional Rural. } \\
\text { Atividades: Coleta de sementes para artesanato } \\
\text { e comércio. } \\
\text { Baixa Infraestrutura. }\end{array}$ & $\begin{array}{l}\text { Homens com atividade de campo/mateiro. } \\
\text { Mulheres trabalho doméstico e coleta de } \\
\text { sementes (12). }\end{array}$ & $\begin{array}{l}\text { Visão de etnomanejo - uso de estratégias para } \\
\text { preservação dos recursos naturais (12). }\end{array}$ \\
\hline $\begin{array}{l}\text { 13. Comunidade Tradicional Ribeirinha. } \\
\text { Agricultura, pecuária, pesca, extrativismo e } \\
\text { artesanato. } \\
\text { Baixa Infraestrutura. }\end{array}$ & $\begin{array}{l}\text { Mulheres responsáveis pela busca de água para } \\
\text { abastecimento manual além do trabalho } \\
\text { doméstico e atividades produtivas como } \\
\text { colheita. Homens responsáveis pelo preparo do } \\
\text { terreno para plantio e serviços pesados (13). }\end{array}$ & $\begin{array}{l}\text { Precarização do sistema ambiental. Entorno } \\
\text { antropizado. Dificuldades no acesso, } \\
\text { manutenção e gestão da água afetam a vida de } \\
\text { mulheres no âmbito doméstico num contexto } \\
\text { que não há escassez de recursos hídricos (13). }\end{array}$ \\
\hline $\begin{array}{l}\text { 14. Comunidade Urbana de Manaus. } \\
\text { Atividade baseada em Criação de gado e } \\
\text { Produção de grãos. } \\
\text { Média Infraestrutura. }\end{array}$ & $\begin{array}{l}\text { Mulheres realizam trabalhos informais como } \\
\text { forma de obter renda complementar. Homens } \\
\text { realizam trabalhos externos. Mulheres com } \\
\text { média dependência financeira (14). }\end{array}$ & $\begin{array}{l}\text { As mulheres são consideradas como } \\
\text { destruidoras ambientais de médio porte. } \\
\text { Ecofeminismo como forma de } \\
\text { empoderamento: melhor condição de vida e } \\
\text { maior participação em relação à natureza não } \\
\text { humana e na natureza construída (14). }\end{array}$ \\
\hline $\begin{array}{l}\text { 15. Comunidade Urbana de baixa renda em } \\
\text { zona metropolitana da cidade. Moradores da } \\
\text { Favela das flores. Principal atividade: } \\
\text { catadoras de materiais recicláveis. } \\
\text { Baixa Infraestrutura. }\end{array}$ & $\begin{array}{l}\text { Responsabilidade de cuidado com o lar e } \\
\text { familiares é feminino. Responsabilidade } \\
\text { financeira é da esfera masculina. Mulheres } \\
\text { atuam na cooperativa para obter renda auxiliar } \\
\text { (15). }\end{array}$ & $\begin{array}{l}\text { Injustiça ambiental associada à desigualdade } \\
\text { de gênero na catação. Mulheres catadoras estão } \\
\text { mais expostas às injustiças ambientais na } \\
\text { cadeia da reciclagem. Vulnerabilidade } \\
\text { ambiental como espaço de resistência, fardo, } \\
\text { oportunidade e desafio cotidiano (15). }\end{array}$ \\
\hline $\begin{array}{l}\text { 16. Comunidade Tradicional Rural de } \\
\text { agricultura familiar, seringa, coleta de } \\
\text { castanha, pesca e extração de madeira. } \\
\text { Baixa Infraestrutura. }\end{array}$ & $\begin{array}{l}\text { Feminino: Cuidado com afazeres domésticos e } \\
\text { filhos. Elas se ocupam do preparo de ervas e } \\
\text { temperos. Homens trabalham com seringais e } \\
\text { praticam pesca de forma diferenciada (16). }\end{array}$ & $\begin{array}{l}\text { Reprodução dos saberes de natureza; Meio } \\
\text { ambiente visto por elas como meio de ação } \\
\text { social e visibilidade (16). }\end{array}$ \\
\hline
\end{tabular}

Fonte: PPGAAI - UNIFESP, Diadema, 2018.

Org.: Dos autores, 2018. 
A referida metodologia compreendeu a aplicação do Diagnóstico Participativo com Enfoque de Gênero - DPEG, com o propósito de aprofundar os conhecimentos e interesses da comunidade, especialmente a feminina, e sua relação com a Proteção Ambiental. O estudo foi desenvolvido em uma Reserva Extrativista na Ponta do Corumbau (BA) e contou com diversos encontros e oficinas que objetivaram ampliar a discussão quanto ao gênero e questões familiares. A autora ressalta que a participação das mulheres ao longo dos encontros elevou-se de tal modo que, em determinado momento, despertou-se a necessidade da criação de seções femininas dentro das Associações de Pescadores. A análise dos resultados depreende-se a amplitude da metodologia no resgate dos testemunhos locais, entendimento dos desafios populacionais, além do seu potencial em dar visibilidade à comunidade feminina e ao despertar o interesse pela sua representatividade política na comunidade. De acordo com Oliveira (2005), a participação feminina, quando oportunizada, fortalece o processo de reconhecimento e valorização do papel social perante a coletividade, favorecendo seu desempenho diante de ações efetivas de poder e decisão diante dos mais variados conflitos e interesses.

\section{Organização social e modo de vida}

Amparado no item anterior, considera-se que a descrição dos modos de vida é parte relevante no processo de análise dos discursos acerca do ecofeminismo. Com base nesta conjectura, variados estudos ausentaram o relato do contexto durante a exposição das publicações. Segundo Storey (2003, p.103), a declaração deste contexto torna-se essencial nos estudos cerceados pelo gênero, pois "o ecofeminismo contesta o universalismo e aceita as diferenças e incertezas que integram o contexto". Segundo a autora os conflitos, representações, identidades demandam clareza para o embasamento de intervenções pontuais apropriadas aos contextos regionais.

Povos e comunidades tradicionais incluindo extrativistas, indígenas, pescadores, quilombolas, ribeirinhos, seringueiros entre outros:

[...] são grupos culturalmente diferenciados e que se reconhecem como tais, que possuem formas próprias de organização social, que ocupam e usam territórios e recursos naturais como condição para sua reprodução cultural, social, religiosa, ancestral e econômica, utilizando conhecimentos, inovações e práticas gerados e transmitidos pela tradição. (BRASIL, Decreto Federal no. 6.040 de 7 de fevereiro de 2007). 
Com relação à organização social e ao modo de vida, no quadro 3 constata-se que 14 entre 16 publicações concentram-se em comunidades tradicionais. Somente os estudos de Valin (2016) e Storey (2003) foram realizados em regiões metropolitanas. Das pesquisas realizadas junto aos povos tradicionais observam-se características semelhantes relativas ao modo de vida. Há execução de atividades de semeadura, colheita e extrativismo amparados, principalmente na agricultura familiar como o identificado por Abreu (2000):

\begin{abstract}
Além do extrativismo vegetal e animal, os moradores do Jaú utilizam, como fonte de renda e de alimento, a agricultura familiar. Usam, para tal, o sistema de pousio que é um sistema característico das populações tradicionais do Amazonas e das unidades de produção familiar, onde a área de cultivo agrícola é regionalmente conhecida como roça. (ABREU, 2000 p. 3).
\end{abstract}

Vale ressaltar que esse sistema de Pousio, muito utilizado na integração ecológica sustentável, foi identificado somente no estudo de Abreu (2000) cuja região recebe implantação de políticas públicas e desenvolvimento de oficinas e encontros voltados a preservação do Parque Nacional do Jaú (AM).

A agricultura familiar, além de caracterizar-se como principal meio de subsistência das comunidades tradicionais, também apresenta uma organização social pautada na construção cultural e histórica destas populações conforme as observações de Peralta e Alencar (2008):

$\mathrm{Na}$ sociedade camponesa (tradicional) não é possível separar as esferas econômica e familiar, dado que a unidade doméstica é ao mesmo tempo uma unidade de produção e de consumo. O objetivo desta unidade de produção é assegurar a reprodução física e social da família e, para isso, é de vital importância garantir a reprodução da força de trabalho atendendo a suas necessidades de consumo. A forma de organização social do trabalho baseada na família pressupõe uma multiplicidade de atividades que são divididas entre seus membros de acordo com o gênero e com a idade. Nessa forma de divisão sexual do trabalho cabe aos homens a responsabilidade pelas atividades de produção, como o cultivo de roças, cuja produção é parte destinada ao consumo e parte ao mercado; e cabem às mulheres as atividades que ocorrem na esfera doméstica, como o cuidado com os filhos, atividades consideradas reprodutivas. (PERALTA; ALENCAR, 2008 p.112).

Quanto às práticas econômicas, os moradores identificam-se essencialmente como seringueiros, lavradores, pecuaristas, pescadores e artesãos, muito embora esse último esteja fortemente atrelado à atuação feminina. A formação de moradores tende a se organizar em comunidades. As condições básicas de sobrevivência como fornecimento 
de água potável, luz, medicamento e atendimento médico, em determinadas localidades inexistem e os meios educacionais geralmente apresentam-se em regiões de entorno com baixa ou inexistente instalação estrutural. De acordo com Abreu (2000), Almeida e Martins (2008), tanto o sistema educacional quanto o de saúde apresentam profundas deficiências em função da realidade local e longínqua das metrópoles que levam os residentes a se organizarem coletivamente na busca de alternativas bem como no aprofundamento dos conhecimentos do meio natural. Segundo os autores, o aprendizado das ervas medicinais e orientação parturiente é compartilhada de geração em geração para amparar a comunidade, reiteradamente esquecida e menosprezada pelo poder público.

Com relação aos modos de vida observados, tanto nas regiões interioranas como nas urbanas, diferenciam-se dos tradicionais essencialmente quanto à infraestrutura e às atividades econômicas exercidas. Numerosos relatos trazidos pelos autores selecionados enfatizam o tipo de trabalho exercido pela esfera masculina majoritariamente formal enquanto a informalidade, quando exercida, afeta mais significativamente o gênero feminino em função da dupla jornada empreendida por elas. Contudo, embora haja relativas discrepâncias entre os modos de vida representados, em torno de $88 \%$ das pesquisas enfatizam a gigantesca desproporção entre as atividades exercidas entre os gêneros que serão expostos e avaliados na categoria adiante.

\section{Gênero e desigualdade na divisão sexual do trabalho}

Na presente categoria analisam-se as principais desigualdades identificadas entre os gêneros quanto ao exercício de variadas atividades produzidas no âmbito das relações sociais e familiares. Ao analisar os resultados alocados no Quadro III diante desta categoria de análise, é possível observar que em todos os casos há forte fragmentação das atividades exercidas por ambos os gêneros. Os autores selecionados relatam que, ainda na contemporaneidade, o papel feminino é intrinsecamente correlacionado à incumbência doméstica bem como ao amplo universo relativo ao bem estar familiar. Nesse contexto, cabe ao marido a competência provedora, protetiva e poder de decisão, intimamente ligado ao potencial de remuneração, como pode ser avaliado no seguinte relato de Almeida e Martins (2008): 
O que se pode perceber também é que em todos os grupos o homem ocupa o espaço de fora, onde o ambiente é amplo, perigoso e exige força, pois lidar com roça e gado é uma atividade própria do homem. Enquanto as mulheres têm o espaço de dentro, a casa como o espaço próprio ao cuidado, à saúde, a educação, a alimentação atividades próprias da mulher. No último caso, o grupo muito fraco a mulher e os filhos só ocupavam e assumiram as atividades com a terra por que este espaço era uma área muito pequena e o homem trabalhava fora nas fazendas dos outros. Mesmo assim o homem continuava a ocupar o papel principal e a mulher o papel secundário no interior deste grupo familiar. (ALMEIDA; MARTINS, 2008, p.9).

Diante da perspectiva teórica retratada durante a revisão, é possível inferir que uma parcela significativa dos estudos evidenciou a reprodutividade dos aspectos históricos e culturais mantidos pelo patriarcalismo e sistema político-capitalista. Esse sistema ditatorial, segundo Braga (2015), documentadamente subjugou o protagonismo feminino e reduziu a própria valoração das atividades exercidas pelas mulheres. Essa diminuição perpetuou-se, segundo Cardoso (2002), em diversas organizações sociais especialmente às tradicionais, reforçada pelos saberes culturais disseminados:

\begin{abstract}
A não consideração do trabalho feminino na pesca é apontada, dentre outros fatores, como resultado da relação hierarquizada entre os gêneros nas próprias comunidades pesqueiras, que vêem apenas os homens como pessoas ligadas à pesca. Essa visão é decorrente da própria formação de pescadores que privilegia a aprendizagem do saber ligado à pesca apenas aos homens, cabendo à mulher outras atividades produtivas. (CARDOSO, 2002 p.7).
\end{abstract}

Ainda com relação à realidade pesqueira, Figueiredo (2011) ressalta que muitas comunidades excluem as mulheres dessas atividades, principalmente quanto à disponibilidade de equipamentos, restando-lhes atividades consideradas fáceis, como é o caso da mariscagem em mangues costeiros que, por se apresentarem acessíveis e de baixo investimento são menos prestigiados.

Em termos de acessibilidade das mulheres às atividades classificadas como tipicamente masculinas, com base nos estudos selecionados, foi possível concluir que as oportunidades de acesso ao universo masculino apresentaram-se como única forma de sobrevivência e subsistência familiar e denota as situações de subjugação e desamparo sofrido por elas no relato de Ana Xavier registrado por Brito (2016):

As explorações aconteciam dentro do barracão também, conforme evidencia Ana Xavier, seus pais eram cearenses, seu pai trabalhou nos barracões, pois sabia fazer contas, ficou cego e foi mandado embora do barracão, sem receber assistência, acabou morrendo, ela e sua família não receberam nada dos 
patrões, Ana Xavier juntos com seus irmãos, tiveram que cortar seringa para sobreviver nas colocações. (BRITO, 2016 p.7).

Além das variadas dificuldades vividas pelas mulheres aqui apresentadas, tornase relevante realizar determinada reflexão quanto ao acesso à saúde. Segundo Brito (2016), as contrariedades vivenciadas por mulheres frequentadoras de espaços hostis, como a realidade do seringal, acontecem tão fundamentalmente quanto o trabalho de parto. Segundo o autor, há muitos casos de maridos e parteiras que as auxiliam neste momento, embora não seja realidade em muitas localidades, e em decorrência das complicações ocorridas durante o processo, muitas gestantes vêm a óbito nas matas. Para Woortmann (1998), ainda há um esforço para garantir a presença de parteiras nas comunidades tradicionais a fim de reduzir a solitude da mulher que da à luz desprotegida em colocações. Para Sousa (2010), esse entre outros tantos tipos de violência contra a mulher têm saído vagarosamente da obscuridade para alcançar o espaço das políticas públicas que, esperançosamente, aguarda por alteridade na realidade de milhares de mulheres em todo o mundo.

Ainda baseado nos resultados angariados pela presente pesquisa, as atividades mais exercidas pela classe feminina, com exceção das incumbências domésticas, apresentam-se quanto a ocupação da mariscagem, limpeza de peixes, semeadura, colheita e elaboração artesanal. Segundo Cardoso (2002), essas atividades são classificadas como essencialmente femininas por envolverem baixo empenho físico e serem compatíveis com a dupla jornada de trabalho desenvolvido por elas:

\footnotetext{
As catadoras são predominantemente mulheres adultas, casadas e com filhos, pois segundo essas mulheres o trabalho da catação permite que se obtenha renda sem necessariamente se afastar do espaço doméstico. Essa preocupação em conciliar trabalho remunerado da catação e o não remunerado trabalho da casa (cuidados com filhos, preparação de alimentos, cultivo de hortas e criação de animais domésticos, dentre outros) está presente somente entre as mulheres com esse perfil, pois as mulheres solteiras e sem filhos buscam trabalho remunerado na sede do município ou em outros municípios da região nordeste do estado do Pará. (CARDOSO, 2002 p.8).
}

De acordo com o relato anterior, averígua-se que as mulheres que têm filhos apresentam-se em situação de maior vulnerabilidade frente à organização social, pois necessitam realizar trabalhos pouco remunerados, cansativos e ainda conciliar essa 
realidade com a doméstica. Para o autor, a catação de caranguejos, mariscagem ou quaisquer atividades que possam oferecer remuneração, ainda que diminuta, são considerados um ganho de status econômico e ampliação do poder de decisão feminino, embora esse ganho seja voltado principalmente ao bem estar familiar como pode ser observado nas conclusões de Machado (2007):

O controle e destino no orçamento doméstico do dinheiro recebido pela massa de caranguejo produzida são estabelecidos pelas catadoras, para compra principalmente de comida: pão, carne e frango. Na medida do possível, o dinheiro é direcionado para compra de material escolar de seus filhos ou roupas, portanto prioritariamente para atender às necessidades das famílias. (MACHADO, 2007 p. 488).

Neste contexto, vale ressaltar as mudanças nas relações sociais que ocorrem no campo doméstico em decorrência do avanço feminino nos espaços políticos e atividades de trabalho. Peralta e Alencar (2008), em seu estudo de acompanhamento de um projeto de Ecoturismo na Reserva de Desenvolvimento Sustentável Mamirauá (AM), revelaram uma série de depoimentos que denotam essas alterações nas relações sociais em uma comunidade tradicional:

\begin{abstract}
Algumas mulheres que tiveram problemas na família depois que foram trabalhar na Pousada, principalmente com os maridos, tentaram se adaptar aos problemas não desistindo do trabalho. Mas aquelas que são muito pressionadas pelos maridos acabam abandonando o trabalho, caso o marido garanta suprir as necessidades da família. Ao abandonar o trabalho elas buscam amenizar os conflitos domésticos e escapar das críticas feitas pelas mulheres mais velhas, mas de certa forma elas estão contribuindo para a continuidade do modelo cultural e do status quo masculino. (PERALTA; ALENCAR, 2008 p. 118).
\end{abstract}

Segundo os autores, além das dificuldades conjugais, as mulheres que assumem atividades no decorrer do projeto apresentaram-se desconfortáveis diante do tempo investido em atividades fora do núcleo familiar e revelam determinada insegurança quanto ao cuidado e educação dos filhos, como pode ser observado no seguinte depoimento:

Tem gente que trabalha no ecoturismo e as crianças ficam na rua (...) - os pais ficam fora e não tem quem cuide delas. Não sabem nem fazer uma comida. Eu acho que se o pai trabalha, a mãe não devia trabalhar. Devia ficar em casa cuidando, ou o contrário. Ou então deixar alguém cuidando da casa dela. Tem criança que está sofrendo porque as mães estão trabalhando fora. O ecoturismo foi muito bom, mas tem também muita gente na perdição, porque não 
souberam trabalhar. Estão se separando, porque não entendem o trabalho (Mulher, 53 anos). (PERALTA; ALENCAR, 2008 p.118).

É possível avaliar que, mesmo diante de alguns conflitos identificados por Peralta e Alencar (2008), ao longo do acompanhamento do Projeto de Ecoturismo, muitos resultados colhidos foram considerados favoráveis especialmente no que tange a independência financeira, visibilidade e poder de decisão feminino dado pela seguinte passagem:

\begin{abstract}
Agora eu tô sozinha, tenho certeza que eu vou viver melhor. Ele ameaçava tocar fogo. Eu queria que ele ajeitasse a casa, ter as coisas. Ele nunca me ajudou. Roupa, calçado, tudo eu que compro. Comprava até para ele, rancho. Depois que eu me separei nem dei falta dele por causa de dinheiro (Mulher, 30 anos). Eu prefiro trabalhar porque a gente não depende do marido, qualquer coisa que quer comprar paga com nosso dinheiro. Porque se é para comprar com salário do marido tem que combinar antes e ele não quer comprar. Eu compro rancho, coisas para mim e para meus filhos. (Mulher, 27 anos). (PERALTA; ALENCAR, 2008 p. 119).
\end{abstract}

De acordo com Valin (2016), que investigou a realidade das catadoras de materiais recicláveis na região metropolitana de São Paulo, embora a dupla jornada empreendida por elas ofereça uma remuneração menor em virtude do tempo de trabalho disponível, a independência e a visibilidade alcançada por elas justificam esse debate e suscitam por novas formas de intervenção e mudança da desigualdade entre os gêneros.

\title{
Representações sobre conservação ambiental
}

De acordo com os resultados presentes no quadro 3 desta categoria de análise, foi possível avaliar que vários estudos (ABREU, 2000; BRITO, 2016; CRUZ, 2010; MONTYSUMA; CRUZ, 2008; SILVA et al., 2014), cerceados pelo ecofeminismo e suas representações ambientais demonstraram uma visão de Conservação Ambiental amparada na preponderância de subsistência, como observa-se no relato de Abreu (2000) com relação a população do Parque Nacional do Jaú (AM):

Outra visão muito comum de natureza entre os moradores do PNJ é a visão antropocêntrica, onde o pensamento manifestado é de que eles podem explorar os recursos, pois são moradores/as do local. Nessa visão, os recursos naturais existem para suprir as necessidades do grupo, e se falam de preservação é porque a consideram como necessária à manutenção de sua subsistência. Ao 
grupo é permitido caçar, pescar etc., e os recursos são usados em seu benefício. (ABREU, 2000, p.6).

De acordo com Rosa et al. (2016), os vínculos entre os ecossistemas e a população devem ser analisados de acordo com os variados contextos em que se inserem, pois esta interação sofre influência da estrutura social junto à questão ambiental. Ao considerar o contexto das comunidades tradicionais, suas concepções refletem a cultura de subsistência como forma de conhecimento técnico que são essenciais para a continuidade das populações nesses espaços e podem consolidar modelo de desenvolvimento sustentável replicável nas demais localidades (BRAGA, 2015; CASTRO; ABRAMOVAY, 2005).

Ainda com relação aos conhecimentos disseminados no interior das culturas tradicionais, Cruz (2010) ressalta que seus habitantes apresentam um modo próprio de se conectar com a floresta e extrair os recursos prioritários para a sobrevivência da comunidade. Segunda a autora, esse ambiente é fonte dos mais variados bens a serviço da comunidade, elencando desde a madeira para fabricação de móveis e moradia à obtenção de alimentos e itens para comércio. Nesse contexto, as mulheres apresentam-se como maiores detentoras de conhecimento tradicional de subsistência, pois historicamente a delegação de cuidado familiar a partir dos recursos ali disponíveis é delas.

\footnotetext{
A gente usa a palha pra fazer bolsa, do broto da palha que é uma coisa que dá, com o tempo cai e já não estraga. Utiliza pra fazer bolsa, pra fazer saia, pra fazer brinco, pra fazer rede, pra fazer manta pra cobrir. A gente tira ela de manhã cedinho, quando tá tudo frio. Tem uma forma que a gente estala ela, puxa ela, ela dá aquele vácuo, aí a gente puxa, tira aquelas linha certinha. Aí a gente deixa ela no sol, depois pega o sabugo do milho - que já não tem mais utilidade - e puxa ela no sabugo do milho, depois passa ela na perna. Na perna a gente emenda uma com a outra e vai fazendo aqueles bolo pra ocupar, pra fazer bolsa, rede, manta, coisa pra colocar de lado pra carregar a criança, todas essas coisas. E do broto da palha a gente faz cesta [...] A gente faz chapéu, faz abanador, faz esteira pra criança sentar pra comer. Tudo isso é coisa que ia ser estragada, ia cair no chão. Então, isso é reaproveitamento que a gente faz de coisa que ia estragar. (Valda Ajuru). (CRUZ, 2010, p. 916).
}

A descrição da organização social dos estudos em comunidades tradicionais permitiu inferir que os modos de vida estão profundamente relacionados com o modelo de desenvolvimento sustentável de suas regiões. Ao observar a coleta de sementes em 
que homens e mulheres participam no interior do Pará desenvolvido por Silva et al., (2014), analisa-se que a atividade sustentável somente é possível pela reconstrução dos papéis sociais entre os membros familiares. Pois, embora os homens apresentem a responsabilidade de abrirem espaços nas matas devido ao nível de periculosidade e risco, as mulheres os acompanham na busca por sementes de maior qualidade para a fabricação das peças que serão comercializadas e ajudarão a compor a renda familiar. Essa construção vem afirmar que não se compreende sustentabilidade inseparável da vida social.

Os resultados desta pesquisa ainda demonstram que em determinados estudos (SOUSA, 2010; STOREY, 2003; MACHADO, 2007) identificou-se que a representação de Meio Ambiente foi categorizada como preponderante para a sobrevivência, porém sem ações efetivas para a sua proteção, inclusive com demonstração de superexploração e ambiente profundamente antropizado. De acordo com Almeida \& Martins (2008), muitas comunidades têm enfrentado a perda de território e são diretamente atingidos pela intensa degradação ambiental decorrente da agricultura mecanizada e acentuado nível de pobreza. É possível que a visão demonstrada pelo povo local seja reforçada pela ausência de projetos de intervenção e políticas públicas voltadas à redução da alteração do ambiente bem como no incentivo de técnicas que os auxiliem na contribuição do bem estar ambiental.

Com relação às pesquisas sociais, apenas duas delas (DI CIOMMO, 2007; PERALTA \& ALENCAR, 2008) ultrapassaram o debate teórico e se propuseram a elaborar projetos de intervenção e, no teor de sua aplicação, alcançaram resultados práticos que asseguraram a participação feminina. Estudo de Peralta e Alencar (2008), ao avaliar a participação social da comunidade após a implantação do Ecoturismo, observou uma elevação na renda familiar, maior participação feminina nos processos decisórios na comunidade, distribuição de benefícios econômicos de modo equitativo, com menor impacto na divisão cotidiana do trabalho. Embora as mulheres participem de atividades produtivas de incumbência doméstica, sua visibilidade e autonomia alcançaram patamares inimagináveis de independência, marcando positivamente a vida desta população.

Diante do exposto, avaliou-se que a maior parte das pesquisas, principalmente, os estudos de caso reproduziam de modo semelhante os referenciais teóricos sobre o tema. 
Contudo, os trabalhos voltados à intervenção demonstraram resultados factíveis, modificaram sensivelmente costumes atrelados à desigualdade, elevando a chance de ganho ambiental.

\section{Considerações finais}

Os resultados demonstram que a escolha da metodologia e a descrição detalhada da organização social e ou meios de vida das comunidades são fundamentais para contextualizar o objeto de estudo. Porém, a historicidade demonstrada pelas relações sociais presentes em parcela significativa dos estudos revelam que na sociedade contemporânea ainda persistem reflexos patriarcais culturalmente construídos. A desigualdade entre os gêneros são reforçados e replicados no âmbito das relações familiares, subjugando gênero feminino e desvalorização da natureza, formando um complexo de injustiça socioambiental.

Constatou-se uma escassez de pesquisa social com desdobramentos práticos e conduzidos de modo a assegurar a participação feminina. Concluiu-se que a múltipla desigualdade que afeta o cotidiano feminino e o tempo gasto para desempenhar papeis e acessar recursos tanto no contexto rural, quanto urbano demandam políticas públicas com instrumentos eficientes em apreender e solucionar essas disparidades. A proposição de políticas públicas poderia ser uma das metas da realização dos estudos envolvendo gêneros nas comunidades tradicionais e no contexto urbano com percepção de riscos. Desenhar estudos de gênero, considerando o contraste rural/urbano com a efetiva participação de mulheres pode atenuar a desigualdade de gênero e a desigualdade social evidenciada principalmente na região norte. $\mathrm{O}$ debate entre gênero, desigualdade social e meio ambiente retratado na literatura ainda que insuficiente contribui para reiterar direitos de meninas-jovens-mulheres em contextos de vulnerabilidade socioambiental.

\section{REFERÊNCIAS}

ANDRADE, D. C; ROMEIRO, A. Serviços ecossistêmicos e sua importância para o sistema econômico e o bem-estar humano. Campinas: IE-UNICAMP, 2009. 155p.

ALMEIDA, V. L. F.; MARTINS, L. C. Relações de Gênero e Educação Ambiental no 
Projeto Mulheres das Águas. In: Encontro Nacional da ANPPAS, 2010, Florianópolis. Anais... Florianópolis: ANPPAS, 2010.

ALONSO, A.; COSTA., V. Ciências Sociais e Meio Ambiente no Brasil: um balanço bibliográfico. BIB - Revista Brasileira de Informações Bibliográficas em Ciências Sociais, ANPOCS. n.53, p.35-78, 2002.

ANGELIN, R. Mulheres, ecofeminismo e desenvolvimento sustentável diante das perspectivas de redistribuição e reconhecimento de gênero. Estamos preparados?

Revista Eletrônica Direito e Política, Itajaí, v.9, n.3, 2014.

ARANTES, R.; GUEDES, V. Mulheres, trabalho e justiça socioambiental. Recife: SOS Corpo - Instituto Feminista para a Democracia, 2010. 99p.

ABREU, M. J. P. Gênero, meio ambiente e modos de vida da população do Parque Nacional do Jaú/AM. In: LISBOA, M.R.A; MALUF, S.W. Gênero, cultura e poder Mulheres, Santa Catarina, v.1, p-145-53, 2000.

BRAGA, F. R. Os movimentos Ecológico-Sociais Femininos e a Luta pela Conservação Ambiental. 41 f. Trabalho de Conclusão de Curso (Especialização em Direito Ambiental) - Departamento de Economia Rural e Extensão, UFPR/Curitiba, 2015.

BRASIL. Decreto $\mathbf{N}^{\mathbf{0}}$ 6.040, de 7 de fevereiro de 2007. Institui a Política Nacional de Desenvolvimento Sustentável dos Povos e Comunidades Tradicionais. Brasília: DOU, 2007.

BRITO, A. L. Trabalhadoras no Seringal: experiência, trabalho, muitas histórias. In XVII Encontro de História da AMPUH-Rio, 2016, Seropédica. Anais... Seropédica: UFRRJ, 2016.

CARDOSO, D.M. Mulher, pesca e ambiente. In: XXV Congresso Anual em Ciência da Comunicação, 2002, Salvador, Anais... Salvador: Intercom, 2002.

CARNEIRO, C. Ecofeminismo e Gestão Planetária. In. XXI Encontro Estadual de História-ANPUH-SP, 2012, Campinas, Anais... Campinas: UNICAMP, 2012.

CASTRO, M.G.; ABRAMOVAY, M. Gênero e meio ambiente. São Paulo: Cortez Editora, 2005. 114p.

CARVALHO, A. V. de. Educação ambiental: o papel das mulheres na preservação do ambiente. Natural Resources, v.6, n.1, p.18-26, 2016.

CAVALCANTI, J. DA S. I.; ALOUFA M. A. I. Percepção de riscos ambientais: uma análise sobre riscos de inundações em Natal-RN, Brasil. Boletín Del Instituto de Geografía, México, n.84, p. 54-68, 2014.

CAVEDON, N. R. O método etnográfico em estudos sobre cultura organizacional: implicações positivas e negativas. In: Encontro Nacional da Associação dos 
Programas de Pós-graduação em Administração, 1999, Foz do Iguaçu, Anais... Foz do Iguaçu: ANPAD, 1999.

CÓRDULA, E. B. D; NASCIMENTO, G. C. C. de. Ecofeminismo na Contemporaneidade. Revista Meio Ambiente e Sustentabilidade, Curitiba. v.2, n.1 2012.

CRUZ TA. Mulheres da floresta do vale do Guaporé e suas interações com o meio ambiente. Revista Estudos Feministas, Florianópolis; v.16, n.3, p.913-25, 2010.

DI CIOMMO, R. C. Pescadoras e Pescadores: a questão da eqüidade de gênero em uma reserva extrativista marinha. Ambiente \& Sociedade. Campinas. v.10, n.1, p.151-63, 2007.

FADIGAS, A.B.M; GARCIA, L.G; HERNÁNDEZ, M.I. As contribuições das marisqueiras para uma gestão sócio-ambiental em reservas extrativistas. Revista Estudos Feministas, Florianópolis v.8, p.1-7, 2008.

FERRE, F. L. Ecofeminismo, democracia e Sustentabilidade. In: XII Seminário Internacional Demandas Sociais e Políticas na Sociedade Contemporânea e VII Mostra de Trabalhos Jurídicos Científicos, Santa Cruz do Sul, 2015

FERREIRA, A. P. L.; MATTOS, L.C. Convergências e divergências entre o feminismo e a agroecologia. Ciência \& Cultura, São Paulo, v.69 n.2, 2017.

FIGUEIREDO, M. M. A mariscagem e as mulheres na baía do Iguape - BA. In: $\mathbf{1}^{\mathbf{0}}$ Seminário de Espaços Costeiros, Salvador (BA). UFBA, 2011.

FLORES, B. N.; TREVISAN, S.D.P. Ecofeminismo e comunidade sustentável. Revista Estudos Feministas, Florianópolis v.23, n.1, p.11-34. 2015.

GARCIA, L. A relação mulher e natureza: laços e nós enredados na teia da vida. Revista Gaia Scientia, João Pessoa v.3 n.1 p.11-16, 2009.

GARCIA, S. M. "Desfazendo os Vínculos Naturais Entre Gênero e Meio Ambiente". Revista Estudos Feministas, Florianópolis n.0/92, p.163-167, 1992.

HERNÁNDEZ, Carmen O. Gênero e Meio Ambiente: a construção do discurso par ao Desenvolvimento Sustentável. Ambiente y Desarrollo, Bogotá v.14, n. 26, p. 13-33, 2010.

HOEFFEL, J. L., SORRENTINO, M.; MACHADO, M. K. Concepções sobre a natureza e sustentabilidade. Um estudo sobre percepção ambiental na bacia hidrográfica do rio Atibainha - Nazaré Paulista/SP. In: II Encontro da ANPPAS, 2004, Indaiatuba, Anais [...] Indaiatuba: ANPPAS, 2004.

JACOBI, P. R.; EMPINOTTI, V; TOLEDO, R.F. Gênero e meio ambiente. Ambiente \& Sociedade, Campinas v.18, n.1, Editorial, 2015. 
JOLY, C. A., HADDAD, C.F.B., VERDADE, L.M., OLIVEIRA, M.C, BOLZANI, V.S.; BERLINCK, R.G.S. Diagnóstico da pesquisa em biodiversidade no Brasil.

Revista USP, São Paulo, 89: 114-33, 2011.

MACHADO, D. Catadoras de caranguejo e saberes tradicionais na conservação de manguezais da Amazônia brasileira. Revista Estudos Feministas, Florianópolis v.15, n. 2, p. 485-90, 2007.

MONTYSUMA, M.; CRUZ, T. A.. "Perspectivas de gênero acerca de experiências cotidianas no Seringal Cachoeira - Acre (1964-2006)". História Unisinos, São Leopoldo v. 12, n. 3, p. 219-236, 2008.

MOURO, H. H. Gênero e Ambiente: Reflexões sobre o papel da mulher na questão socioambiental. 106 f. Dissertação (Mestrado em Ecologia Humana e Problemas Sociais Contemporâneos). FCSH, Lisboa, 2017.

OLIVEIRA, N. Grupos Mulheres da Terra: abordagem fundamentada no ecofeminismo e na alfabetização ecológica. Mulher e Trabalho, Porto Alegre v. 5, p. 101-12, 2005.

PACHECO, M. E. L. Em defesa da agricultura familiar sustentável com igualdade de gênero. In: GT Gênero - Plataforma de Contrapartes Novib/SOS Corpo. Perspectivas de gênero: debates e questões para as ONGs. Gênero e Cidadania, Recife, 2004.

PERALTA, N.; ALENCAR, E. D. Ecoturismo e Mudança Social na Amazônia Rural: efeitos sobre o papel da mulher e as relações de gênero. Campos (UFPR) Curitiba, v. 09, n.1, p. 109-29, 2008.

PINHEIRO, J. Q.; GUNTHER, H.. Métodos de pesquisa nos estudos pessoaambiente. São Paulo: Casa do Psicólogo, 2008, 396p.

ROSA, V. M.; SOUSA, K. F.; SZULCZEWSKI, N. A. S.; CARVALHO, A. V.. Educação ambiental: o papel das mulheres na preservação do ambiente. Natural Resources, Sergipe v.6, n.1, p.18-26, 2016.

ROSSINI, R. E.; CALIÓ, S. A. Gênero e meio ambiente na Amazônia brasileira. In: Conferência Internacional - Fazendo Gênero 8, 2008, Florianópolis. Anais [...] Florianópolis: UFSC, 2008.

SILIPRANDI, Emma. "Ecofeminismo: contribuições e limites para a abordagem de políticas ambientais". Agroecologia e desenvolvimento sustentável, Porto Alegre v.1, n. 1, p. 61-71, jan./mar, 2000.

SILVA, S. A. Ecofeminismo: em defesa da dignidade das mulheres e da natureza. In: Simpósio Internacional de Mariologia, 2017, Recife, Anais [...] Recife: Semana Teológica da UNICAP, 2017. 
SILVA, R. E.; BONFIM, F. da S.; SOUSA, R. R. Gênero e Floresta. Revista Gênero e Direito, João Pessoa, v.3 n.1, p.1-12, 2014.

STOREY, C. Representações Sociais e Meio Ambiente: participação de um grupo de mulheres no planejamento de uma intervenção de Educação Ambiental popular urbana em Manaus. 199 f. Tese (Doutorado em Ciências). Programa de Pós-graduação em Ecologia e Recursos Naturais, UFSCAR, São Carlos, 2003.

SOUSA, M. A. S. Gênero e Meio Ambiente na Amazônia Roraimense: Um olhar sobre o Encontro da Água com a vida das Mulheres do Projeto de Assentamento Equador, Rorainópolis. 158 f. Dissertação (Mestrado em Recursos Naturais). Programa de Pósgraduação em Recursos Naturais, UFRR/Boa Vista, 2010.

SOUZA, I. P.; RAMÍREZ-GÁLVEZ, M.C. Os sentidos e representações do ecofeminismo na contemporaneidade. In: Seminário de Pesquisa em Ciências Humanas, 2008, Londrina. Anais [...] Londrina: UEL, 2008.

TONI, A; RÉGIA, M.; GROSSI, M.; CORRAL, T.; DI CROCE, S. Mulheres e Sustentabilidade. Sustentabilidade em Debate, Brasília, v. 5, n.2, p. 108-21, 2014.

TORNQUIST, Carmem Susana; LISBOA, Teresa Kleba; MONTYSUMA, Marcos Freire. Mulheres e Meio Ambiente. Revista Estudos Feministas, Florianópolis v.16, n.3, p.865-69, 2010.

TORRES, Maximiliano. O ecofeminismo: um termo novo para um saber antigo. Revista Terceira Margem, Rio de Janeiro, v.13, n.20, p.157-75, 2009.

VALLIN, I.C. Gênero e Meio Ambiente: dupla jornada de injustiça ambiental em uma cooperativa de mulheres catadoras de materiais Recicláveis. $152 \mathrm{f}$. Dissertação (Mestrado em Ciências) - Instituto de Energia e Ambiente, USP/São Paulo, 2016.

VIEIRA, B. B.; AZEVEDO, M. A. M.2008. Ecofeminismo: a mulher rural como fomentadora dos saberes etnobotânicos e lutas ambientalistas. In: $7^{\circ}$ Simpósio de Gestão Ambiental e Biodiversidade, 2018. Seropédica. Anais [...] Seropédica: UFRRJ, 2018.

WOORTMANN, E. F. Família, mulher e meio ambiente no seringal. In: NIEMEYER, A.M.; GODOI, E.P. Além dos territórios: para um diálogo entre a etnologia indígena, os estudos rurais e os estudos urbanos. Campinas: Mercado de Letras, 1998. p.167-200. 